\title{
TOTAL PHOSPHORUS AS AN INDICATOR OF TROPHIC STATE OF PORTUGUESE RESERVOIRS
}

\author{
M. J. Boavida \& R. T. Marques \\ Dept. Zoologia, Faculdade de Ciências da Universidade de Lisboa, Campo Grande, C2, 1700 Lisboa. Portugal.
}

\begin{abstract}
Total phosphorus was determined for the 44 most important reservoirs all over the country. The objectives were to map phosphorus in Portuguese reservoirs and to determine their trophic state. Total phosphorus, dissolved oxygen concentration, and $\mathrm{pH}$ were measured in the fall of 1992 in reservoirs ranging from North to South of Portugal, covering the rivers Lima, Cávado, Ave, Douro, Mondego, Tejo, Sado, Morgável, Mira, Odiáxere, Arade and Guadiana watersheds. Factors such as geographical location, morphometry, geology, surrounding land use, climate, and position in the river continuum influenced water quality of the reservoirs. Of the reservoirs sampled, $40 \%$ were classified as eutrophic, the remaining as mesotrophic. There is an urge to recover the most productive of the studied reservoirs, as well as to prevent further degradation of those still considered as mesotrophic.
\end{abstract}

Palabras clave: Fósforo total, Estado trbfico, Embalses, Portugal. Keywords: Total Phosphorus, Trophic State, Reservoirs, Portugal

\section{INTRODUCTION}

Portugal is a country with very few natural lakes and therefore where reservoirs fulfill the function of retaining water for the most diversified uses. There are circa 100 operational reservoirs in the country. Mainly built for drinking water supply, irrigation, and electric power generation, these artificial lakes arc also utilized for fishing and recreational purposes.

Freshwater resources in Portugal are scarce. Rainfall is irregular and not abundant, especially in the inland areas where the influence of the sea does not ameliorate the harsh caracter of the climate. With the exception of the $2000 \mathrm{~m}$ altitude mountain in the central part of the country, it is frequent to have several (up to three or four) years in a row with practically no rainfall. The few rain events usually take place during winter. Even rivers of appreciable dimension (third or fourth order streams) are characterized by very irregular flow; there are cases, e.g. the River Guadiana, a fourth order river in the south, where totally dry portions of the river bed can be seen in summer, alternating with pools where some stagnant water is left. Cases such as this just described illustrate the dryness of the country climate.

Similarly to what happens at a global level, water quality in the majority of Portuguese reservoirs is threatened by increasing eutrophication. The key role played by phosphorus loads in eutrophication has been object of special attention for long (VOLLENWEIDER, 1968; WETZEL, 1983). Empirical relationships between phosphorus loading and algal biomass are often based on total phosphorus concentrations (VOLLENWEIDER, 1976). Total phosphorus concentrations are, therefore, commonly used to assess the degree of eutrophication as a result of nutrient enrichment of lakes.
There is often a good correlation between total phosphorus concentrations and algal standing crop in a great variety of lakes.

According to WETZEL (1990) reservoirs and natural lakes are functionally alike, being the basic ecological processes occurring in them and their controlling factors the same; the differences are often found in the rates at which those processes take place (usually higher rates in reservoirs than in natural lakes).

The purposes of this research were (1) to determine the total phosphorus concentrations of Portuguese reservoirs, from north to south, so that concentrations could be shown pictorially on a map, and (2) based on total phosphorus concentrations, to determine the trophic state of the reservoirs. There is a lack of this type of studies in Portugal, where reservoirs have so far been studied on an individual basis (one at a time). This study was intended to be integrated both at watershed and country levels. Since lake (or reservoir) ecosystems cannot be viewed independently of their drainage baisins, or watersheds, total phosphorus concentrations were thus related to other factors such as geology, soil composition, land use, precipitation, humidity, insolation, air temperature, surface area and volume of the reservoirs, dissolved oxygen concentrations of the water, and alkalinity of the soil. The ultimate goal of this research was to provide data for correct, integrated management of the Portuguese reservoirs.

\section{MATERIALS AND METHODS}

This study was undertaken at a period following a 2-year drought in the country. For this reason, of the circa 100 reservoirs in use, only 44 (the largest) were sampled. Most of the remaining are relatively small and were almost dry at the 
tıme of sampling, therefore wcre disregarded. A few others wcre not sampled because of logistic dificulties.

Each of the 44 reservoirs was sampled once, between mid September and beginning of October of 1992. These 44 water bodies belong to 12 river watersheds (Fig. 1) and are distributed among them as follows: 6 to R. Cávado, 2 to R. Ave, 5 to R. Douro, 3 to R. Mondego, I I to R. Tejo, 5 to R. Guadiana, 7 to R. Sado, and 1 to each of rivers Lima, Mira, Arade, Odiáxere, and Morgável.

Water samples for total phosphorus (TP) deterinination wcre collected from the upper $02 \mathrm{~m}$ stratum into acid rinsed polyethylene bottles Water temperature and dissolved oxygen concentrations were recorded in situ with a YSI model 57 thermometer-oxymeter. Indicator $\mathrm{pH}$ paper (Johnsons of Hedon, Ltd.) was utilized in the field for approximate $\mathrm{pH}$ determinations.

Total phosphorus was determined after acid hydrolysis with persulfate for 60 minutes under high temperature and pressure followed by the MURPHY \& RILEY (1962) spectrophotornetric method on 5 replicates. Carlson's Trophic State Index (CARLSON, 1977) was the criterion for trophic classification of the rescrvoirs.

\section{RESULT}

TP and age of the reservoirs: Portuguese reservoirs are all relatively recent; of those studied, Póvoa (built in 1927, R. Tejo) was the oldest and Lindoso (built in 1992, R. Lima) had been filled up for the first time about six months before sampling for this research was undertaken. A significant positive correlation $(\mathrm{P}<0.05, \mathrm{n}=44)$ was found between $\mathrm{TP}$ and the yeas of construction of the rescrvoirs

TP and surface area of the rcservoirs: Sampled rescrvoirs were divided into four classes according to their surface area (class A > 1900 ha; class B from 600 ha up to 1900 ha; class C from 100 ha up to 500 ha; class $D<100$ ha). The largest reservoirs were located in rivers Douro, Tejo, and Sado watersheds (Table I). Regarding the above classification 36.4 $\%$ of the studied reservoirs belong to class B and $40.9 \%$ belong to class $\mathrm{C}$, being both very large and very small rcservoirs relatively few. A significant correlation was not found between TP and surface area of the reservoirs.

$\mathrm{TP}$ and trophic state of the reservoirs: In figures 2, 3 and 4 the 44 rcservoirs are depicted in their respective watersheds ( 2 - rivcrs Lima, Cávado, Avc, and Douro; 3 - rivers Mondego and Tejo; 4 - rivers Sado, Guadiana, Morgável, Mira, Odiaxcre, and Arade) with indication of relative magnitudes of $\mathrm{TP}$, dissolved oxygen (DO) and $\mathrm{pH}$. Absolute values for all of these parameters arc indicated on Table 1 TP was used to compute Carlson's Trophic State lndex (CARLSON, 1977) Based on this index (phosphorus component only) the rescrvoirs were classified according to trophic stale. Twenty seven rcservoirs were considered as mesotrophic and seventeen were considered as eutrophic. The watershed with

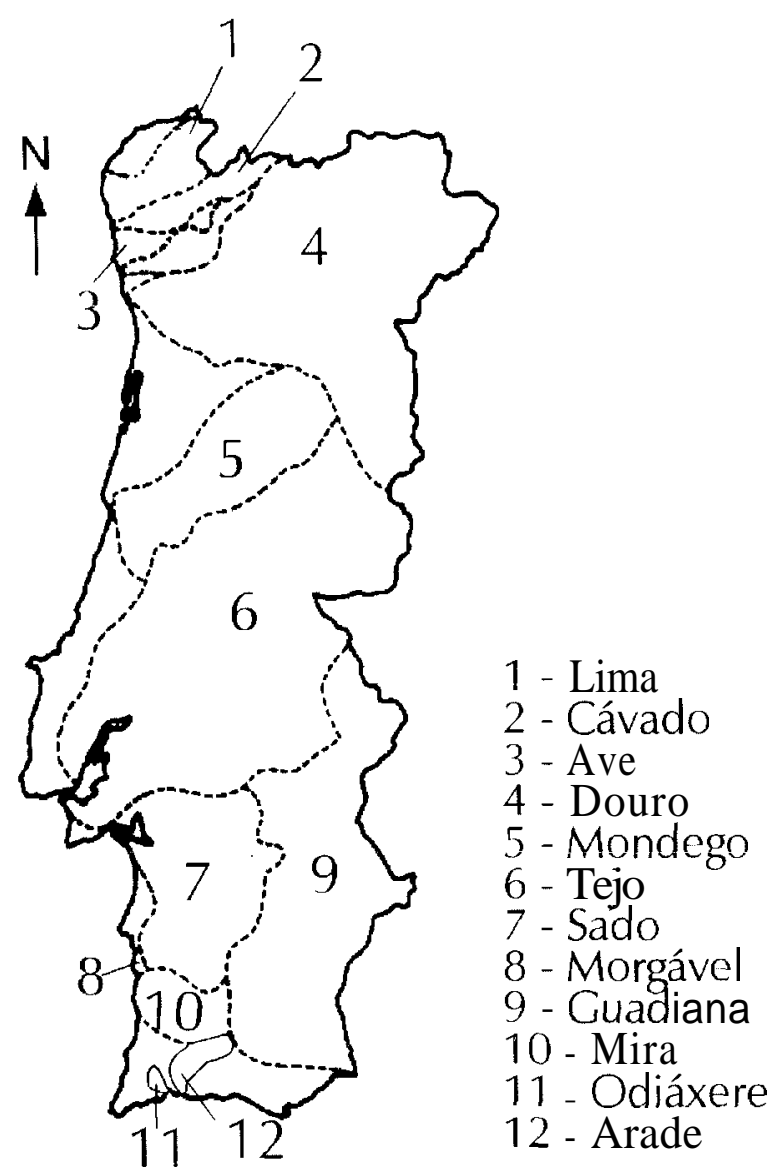

Figure I. Location in the map of Portugal of the 12 drainage basins sampled Figura I. Locnlizacion de las 12 cuencas muestreadas en Portugal.

the lowest percentage of eutrophic rescrvoirs was that of R. Sado (15\%). The highest percentage of eutrophic reservoirs was concentrated on R. Tejo watershed $(64 \%)$.

TP and dissolved oxygen in the water of the reservoirs: The highest values of DO concentration in lake water wcre recorded for R. Sado watershed reservoirs, the lowest for R. Tejo watershed rcservoirs (Figs. 3 and 4). There was a significant negative correlation between surface DO and TP in the 44 reservoirs.

$\mathrm{TP}$ and $\mathrm{pH}$ of the water of the reservoirs: Water $\mathrm{pH}$ varied between 5 and 5.5 in R. Cávado watershed, was 5.5 for all reservoirs of rivers Lima, Ave, and Mondego, varied beteen 5.5 and 6.7 in R. Tejo watershed. between 5.8 and 6.7 in R. Guadiana watershed, and between 5.5 and 6.4 in R. Sado watershed (Table 1). There was no correlation between water $\mathrm{pH}$ and TP of the reservoirs. 
Table I. Some morphometric and chemical characteristics of the sampled reservors. Y.C. = year of construction: volume in $\mathrm{m}$ ' $\times 10^{\prime \prime}$; area in surface area, in ha, followed by a letter representung the area class: TP in $\mu \mathrm{g} / \mathrm{l} ; \mathrm{O} 2 \mathrm{in} \mathrm{mg} / \mathrm{l}$.

Tabla I. Características morfométricas y quínicas de los embalses estudiados. Y. C. año de construcción; volumen en m’ $10^{\prime \prime}$ : área (corresponde a área superficial) en ha. seguida de una letra que indica la clase: TP en $\mu \mathrm{g} / \mathrm{l} ; 0 . \mathrm{en} \mathrm{mg/l.}$

\begin{tabular}{|c|c|c|c|c|c|c|c|}
\hline RESERVOIR & WATERSHED & Y.C. & VOLUME & AREA & TP & $\mathrm{O}_{2}$ & $\mathrm{pH}$ \\
\hline Lindoso & Lima & 1992 & 348 & $1072 \mathrm{~B}$ & 81.37 & 4.5 & 5.5 \\
\hline A. Rabagáo & Cávado & 1964 & 569 & $2200 \mathrm{~A}$ & 29.76 & 5 & 5.2 \\
\hline V. Nova & Cávado & 1951 & 97 & $400 \mathrm{C}$ & 29.1 & 5.5 & 5.2 \\
\hline Salamonde & Cávado & 1953 & 63 & $242 \mathrm{C}$ & 48.94 & 4.8 & 5.5 \\
\hline Caniçada & Cávado & 1955 & 153 & $689 \mathrm{~B}$ & 83.28 & 4.8 & 5.5 \\
\hline V. Furnas & Cávado & 1972 & 118 & $346 \mathrm{C}$ & 80.03 & 9.3 & 5 \\
\hline Penide & Cávado & 1951 & 0.5 & $69 \mathrm{D}$ & 56.95 & 10.3 & 5.5 \\
\hline Guilhofrei & Ave & 1938 & 22 & $1630 \mathrm{~B}$ & 101.49 & 4 & 5.5 \\
\hline Andorinhas & Ave & 1945 & 1.2 & $21 \mathrm{D}$ & 48.52 & 3.8 & 5.5 \\
\hline Pocinho & Douro & 1982 & 81 & $830 \mathrm{~B}$ & 84.46 & 7.5 & 6.7 \\
\hline Vilar & Douro & 1965 & 100 & $670 \mathrm{~B}$ & 58.78 & 6.2 & 6.7 \\
\hline Carrapatelo & Douro & 1972 & 140 & $952 \mathrm{~B}$ & 52.3 & 5 & 6.7 \\
\hline Torráo & Douro & 1988 & 124 & $651 \mathrm{~B}$ & 28.99 & 3.4 & 6.4 \\
\hline C. Lever & Douro & 1985 & 106 & $420 \mathrm{C}$ & 57.41 & 5.5 & 6.7 \\
\hline Fagilde & Mondego & 1984 & 2.8 & $7.5 \mathrm{D}$ & 12.94 & 5.8 & 5.5 \\
\hline Aguieira & Mondego & 1981 & 450 & $2000 \mathrm{~A}$ & 47.31 & 5.7 & 5.5 \\
\hline Raiva & Mondego & 1981 & 21 & $300 \mathrm{C}$ & 103.85 & 3.3 & 5.5 \\
\hline Idanha & Tejo & 1949 & 78 & $678 \mathrm{~B}$ & 81.19 & 3.7 & 5.5 \\
\hline Póvoa & Tejo & 1928 & 22 & $236 \mathrm{C}$ & 83.5 & 4.3 & 5.5 \\
\hline Fratel & Tejo & 1973 & 93 & $750 \mathrm{~B}$ & 110.95 & 4 & 6.7 \\
\hline Marateca & Tejo & 1991 & 37 & $634 \mathrm{~B}$ & 80.62 & 3.8 & 5.5 \\
\hline Belver & Tejo & 1952 & 13 & $286 \mathrm{C}$ & 108.58 & 5 & 6.7 \\
\hline S.ta Luzia & Tejo & 1942 & 54 & $246 \mathrm{C}$ & 45.73 & 5.5 & 5.5 \\
\hline Cabril & Tejo & 1954 & 719 & $2033 \mathrm{~A}$ & 57.27 & 5.2 & 5.5 \\
\hline C. Bode & Tejo & 1951 & 1100 & $3291 \mathrm{~A}$ & 56 & 5.2 & 5.5 \\
\hline Maranhxo & Tejo & 1957 & 220 & $1960 \mathrm{~A}$ & 110.01 & 3.2 & 6.1 \\
\hline Montargil & Tejo & 1958 & 180 & $1646 \mathrm{~B}$ & 86.33 & 4.5 & 6.1 \\
\hline Divor & Tejo & 1965 & 12 & $239 \mathrm{C}$ & 39.98 & 6.9 & 6.1 \\
\hline Gaia & Guadiana & 1967 & 203 & $1970 \mathrm{~A}$ & 77.61 & 6.4 & 6.1 \\
\hline Vigia & Guadiana & 1981 & 17 & $262 \mathrm{C}$ & 26.22 & 5.2 & 6.1 \\
\hline M. Novo & Guadiana & 1982 & 15 & $277 \mathrm{C}$ & 35.97 & 6.6 & 6.7 \\
\hline T. Grande & Guadiana & 1984 & 10 & $150 \mathrm{C}$ & 33.98 & 5.8 & 5.8 \\
\hline Beliche & Guadiana & 1986 & 48 & $292 \mathrm{C}$ & 27.15 & 8.1 & 5.8 \\
\hline M. Rocha & Sado & 1972 & 105 & $1100 \mathrm{~B}$ & 34.38 & 5.5 & 6.1 \\
\hline Campilhas & Sado & 1954 & 22 & $333 \mathrm{C}$ & 70.06 & 7.2 & 5.8 \\
\hline F. Serne & Sado & 1977 & 5.2 & $105 \mathrm{C}$ & 45.91 & 7.5 & 5.8 \\
\hline Roxo & Sado & 1968 & 96 & $1378 \mathrm{~B}$ & 37.6 & 9.3 & 6.1 \\
\hline Alvito & Sado & 1977 & 133 & $1480 \mathrm{~B}$ & 25.73 & 8.3 & 6.4 \\
\hline Odivelas & Sado & 1972 & 96 & $973 \mathrm{~B}$ & 26.22 & 11.6 & 6.4 \\
\hline P. Altar & Sado & 1949 & 94 & $876 \mathrm{~B}$ & 62.25 & 5.2 & 6.4 \\
\hline Morgável & Morgável & 1980 & 33 & $340 \mathrm{C}$ & 26.62 & 8.1 & 6.7 \\
\hline S.ta Clara & Mira & 1968 & 485 & $1986 \mathrm{~A}$ & 20.57 & 6.4 & 6.1 \\
\hline Bravura & Odiáxere & 1958 & 35 & $285 \mathrm{C}$ & 80.36 & 8 & 5.8 \\
\hline Arade & Arade & 1955 & 28 & $182 \mathrm{C}$ & 103.76 & 4.5 & 6.4 \\
\hline
\end{tabular}


TP and climatic and soil characteristics affecting the reservoirs: Data for rainfall, alkalinity of the soil, drainage, annual variation of air humidity, hours of insolation, evapotranspiration, and air temperature of the areas where reservoirs are located were collected from an Environment Atlas (ATLAS DO AMBIENTE, 1975, 1978, 1980) or kindly supplied by the Institute of Meteorology (Instituto Nacional de Meteorologia, Lisboa, Portugal) and used in the regressions. All data of the Environment Atlas and specially those for rainfall must be faced in a general way, since the last editions of the Atlas refer to a decade earlier. However, more recent data for rainfall were obtained from the Institute of Meteorology. Even so, since in the two years previous to this study there was practically no rainfall in the whole country, the conclusions of the respective regressions should be taken as the usual tendency. The reservoir affected by the highest values of precipitation was V. Furnas (> $2800 \mathrm{~mm} /$ year) in R. Cávado watershed. The lowest recorded values for annual precipitation corresponded to T. Grande and Beliche, two reservoirs of the R. Guadiana watershed $(400-500 \mathrm{~mm} /$ year). Soil $\mathrm{pH}$ was Sound to be quite acid (between 4.5 and 5.5) in rivers Cávado, Lima, Ave and Mondego watersheds, less acid (between 5.5 and 6.5) in rivers Douro and Tejo watersheds, and around neutral (between 6.5 and 7.4) in rivers Guadiana and Sado watersheds. A significant negative correlation was found between rainfall and the $\mathrm{pH}$ of the surrounding soils for all 44 reservoirs sampled. A significant negative correlation was also found both between rainfall and alkalinity of the soil and between rainfall and runoff. A significant positive correlation was found between runoff and alkalinity of the soil. Runoff is more intense into the northern reservoirs of rivers CBvado and Ave watersheds. The reservoir V. Furnas, in R. Cávado watershed, is subjected to more than $2200 \mathrm{~mm}$ precipitation, therefore it is probably one of the reservoirs affected by very high runoff from the surrounding land. In the south of the country, the reservoirs least affected by runoff are mainly those of the rivers Guadiana and Sado watersheds; the lowest values for precipitation $(50-100 \mathrm{~mm})$ corresponded to T. Grande (R. Guadiana) and F. Serne (R. Sado). Humidity is highest in rivers Cávado and Sado watersheds (75-85\%) and lowest in R. Tejo watershed; the lowest found value for humidity was recorded for Marateca Reservoir (R. Tejo). Nevertheless there is not a large variation in humidity throughout the country at a watershed scale. Conversely, annual insolation is highest for the reservoirs in the R. Guadiana watershed (Vigia, M. Novo, and T. Grande exhibited the highest values: 300-3100 hours per year). The highest evapotranspiration values $(700-800 \mathrm{~mm}$ per year) were attributed to the reservoirs in the rivers CBvado and Ave watersheds, in the north of the country. Lowest mean annual air temperature was recorded for some of the reservoirs in the R. Cávado watershed (A. Rabagão, V. Nova, and V. Furnas, 7.5-10 "C). Highest mean annual air temperature was recorded for the rivers Guadiana and Sado watersheds reservoirs ( $T$.
Grande, R. Guadiana, more than 17.5 "C). Regarding the geology, soil composition, and land use around the reservoirs throughout the country: Almost all reservoirs in rivers CBvado and Ave watersheds were constructed on calcium-alkaline granitic soils, with the exception of A. Rabagão and V. Nova reservoirs (R. Cávado). The latter are located on soils which also contain some schist. The reservoirs in the rivers Douro, Mondego, and Tejo watersheds are located either on soils mainly composed of calcium-alkaline granites or on predominantly schistous soils. It was not found a relationship between TP and any of the above described characteristics.

$\mathrm{TP}$ and population density in the reservoirs area: Almost all studied reservoirs are located in areas of relatively low population densities, The reservoirs of R. Douro watershed are located in the most densely populated areas (100-250 ind./Km $\left.{ }^{2}\right)$ among those sampled, with the only exception of Pocinho $(<20$ ind. $\left./ \mathrm{Km}^{2}\right)$. R. Sado reservoirs are affected by the lowest population density of all the reservoirs sampled $\left(<20\right.$ ind. $\left./ \mathrm{Km}^{2}\right)$. There was not a significant correlation between TP and population densities in the reservoirs catchment areas when the whole set of reservoirs was analysed i.e. at country level.

Correlations were also tried at the drainage basin level, between several environmental variables and the parameters intrinsic to the limnology of the reservoirs, TP included, for all reservoirs of the same watershed. For R. Cávado watershed only one significant positive correlation was found between water $\mathrm{pH}$ and volume of the reservoirs. For R. Douro watershed five significant negative correlations were found: $\mathrm{TP}$ and rainfall, TP and population density, TP and evapotranspiration, dissolved oxygen and volume of the reservoirs, water $\mathrm{pH}$ and volume of the reservoirs. For R. Guadiana watershed there were two significant negative correlations (dissolved oxygen and evapotranspiration, and volume of the reservoirs and cvapotranspiration) and two significant positive correlations (TP and surface area of the reservoirs, and $\mathrm{TP}$ and soil $\mathrm{pH}$ ).

Principal Components Analysis (PCA) was applied to the data of five of the watersheds sampled: those of rivers Cávado, Douro, Tejo, Guadiana, and Sado. These watersheds were chosen because they were the most representative in terms of number of reservoirs sampled. TP exhibited the best absolute score in the first axis for all but R. Guadiana watershed. The first factor accounted for respectively $64 \%$ of the variance in R. Cávado watershed, $75 \%$ in R. Douro watershed, $76 \%$ in R. Tejo watershed. and $70 \%$ in R. Sado watershed.

PCA was also run for the whole set of 44 reservoirs (country level analysis). The measure of sampling adequacy (KaiserMeyer-Olkin) was mediocre, therefore those results are not presented here.

\section{DISCUSSION}

The purposes of this study -to map TP concentrations ot the Portuguese reservoirs and to classify them according to trophic state- assume greater relevance as cultural eutrophication 

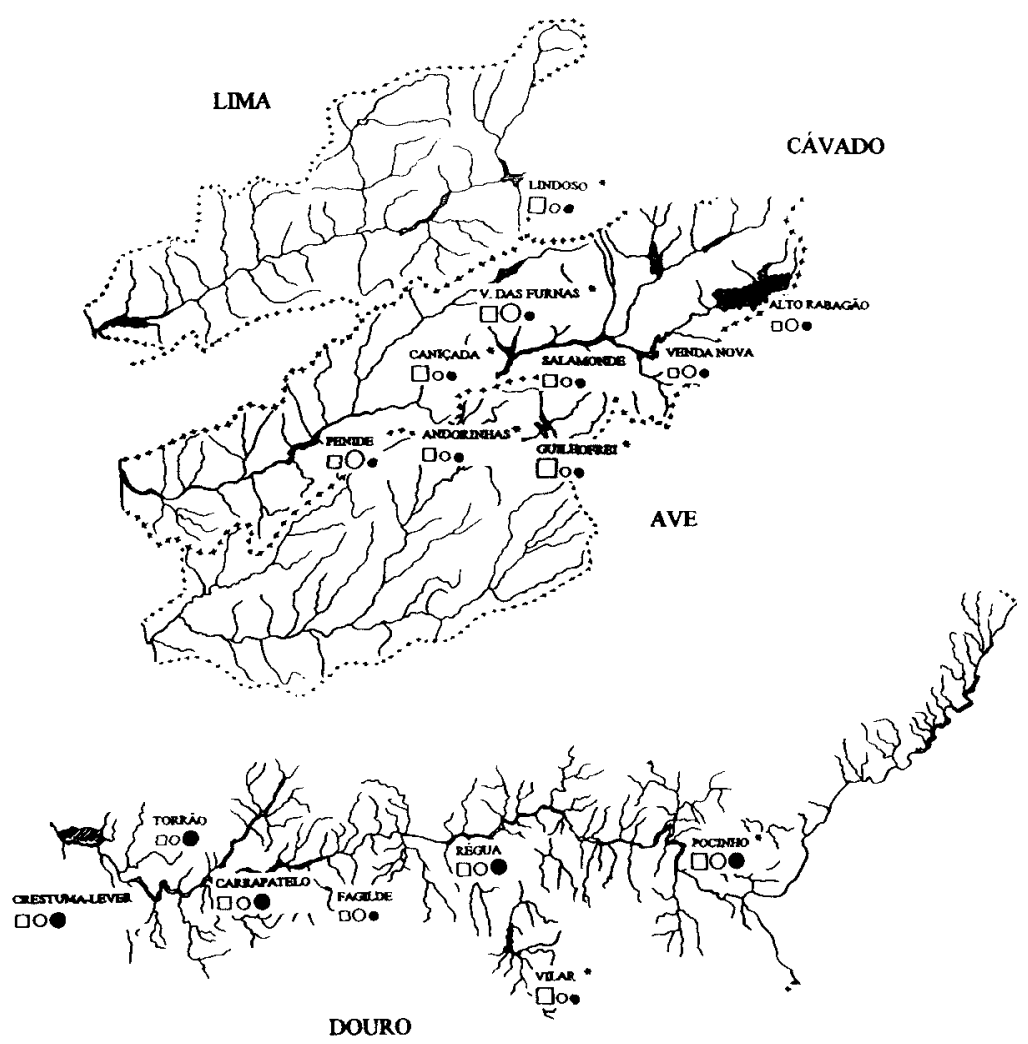

Figure 2. Localion of the reservoirs in rivers Lima, Cávado, Ave, and Douro watersheds. Relative magnitudes of TP $(\square)$, DO $(0)$, and water $\mathrm{pH}(\bullet)$ are provided, incl-easing quantitites corresponding to increasing stzaes of the respective symbols. Eutrophic reservoirs are marked with an asterisc. Figura 2. Localización de los embalses en las cuencas de los rios Lima, Cávado, Ave y Duero. Se incluyen las magnitudes relativas de TP $(\mathbb{C})$. DO $(\mathrm{O})$, y pH $(\bullet)$ del agua, a través del tamaño creciente de los símbolos respectivos. Los embalses eutróficos se señalan con un asterisco. about a decade ago: After the dam was built, only large, tall trees would be removed from the prospective lake basin, all other vegetation left in place; as a consequence of inundation, many nutrients (phosphorus surely included) would be released into the water over a relatively short time. In addition, 30-40 years ago it was a common procedure to release domestic sewage of small towns and villages to the reservoirs almost with no treatment (most of the small towns would go no further than secondary treatment at the time).

As contradictory as it seems, it was not observed a significant correlation between TP and population density at country level. This might be because population densities are in general low in the catchment areas and especially because sewage and industrial effluents treatment has been being emphasized during the last decade. The relationship between TP and population density would have been better studied if the area of land draining into each reservoir was also considered. This was not done because such areas were not known with precision for most of the studied reservoirs. It was thought, however, that population density per se would somehow reflect that.

It could be argued that, because of the way $\mathrm{pH}$ was estimated in the field (with indicator paper), there was no point in trying to find a correlation between this water parameter and TP. It is true that $\mathrm{pH}$ values for the water of the reservoirs could have been underestimated as a result of the method used. However, it was estimated in the same way for all the reservoirs, this rendering the values comparable. On the other hand, soil $\mathrm{pH}$ was acid (data obtained from the Environment Atlas) for most of the watersheds studied, except those of the rivers Guadiana and Sado. This may be an

increases. First of all it is necessary to know these values to effectively manage the reservoirs. Often in these latitudes and because of the dryness of the weather TP values in August September (time of the year samples were taken) are below annual maxima. However, it is best to take as reference for this kind of study values lower than maxima to avoid interpretations based on extreme measurements. On the other hand, it is only with ecosystems perspectives that an efficient management can be achieved. As WETZEL (1996) pointed out, limnological expertise is required to understand the mechanisms regulating the operation of freshwater ecosystems; because limnology is an integrative discipline, it offers the only possible, encompassing way of facing, and eventually solving, eutrophication.

Among the relationships found for Portuguese reservoirs, the significant positive correlation between TP and the age of the reservoirs may reflect the procedure generalized up until indication that water $\mathrm{pH}$ might not have been underestimated.

Although some of the obtained correlations (e.g. $\mathrm{DO} /$ volume of the reservoir, DO/evapotranspiration, TP/soil $\mathrm{pH}$ ) were statistically significant, they have no ecological meaning. PCA was performed considering those variables with ecological meaning since the objective of this analysis is to group sampling units according to their ecological resemblances.

TP exhibited the best absolute score in the first axis for PCA on all but one of the five most representative watersheds. TP was the variable used to compute Trophic State Index. In spite of the recommendation of the author of the Index that chlorophyll is the best indicator when one component of the index is used alone, TP coming next (CARLSON. 1977), PCA results reinforce the argument that TP gives a good estimate of trophic state, at least in Portuguese reservoirs. According to 


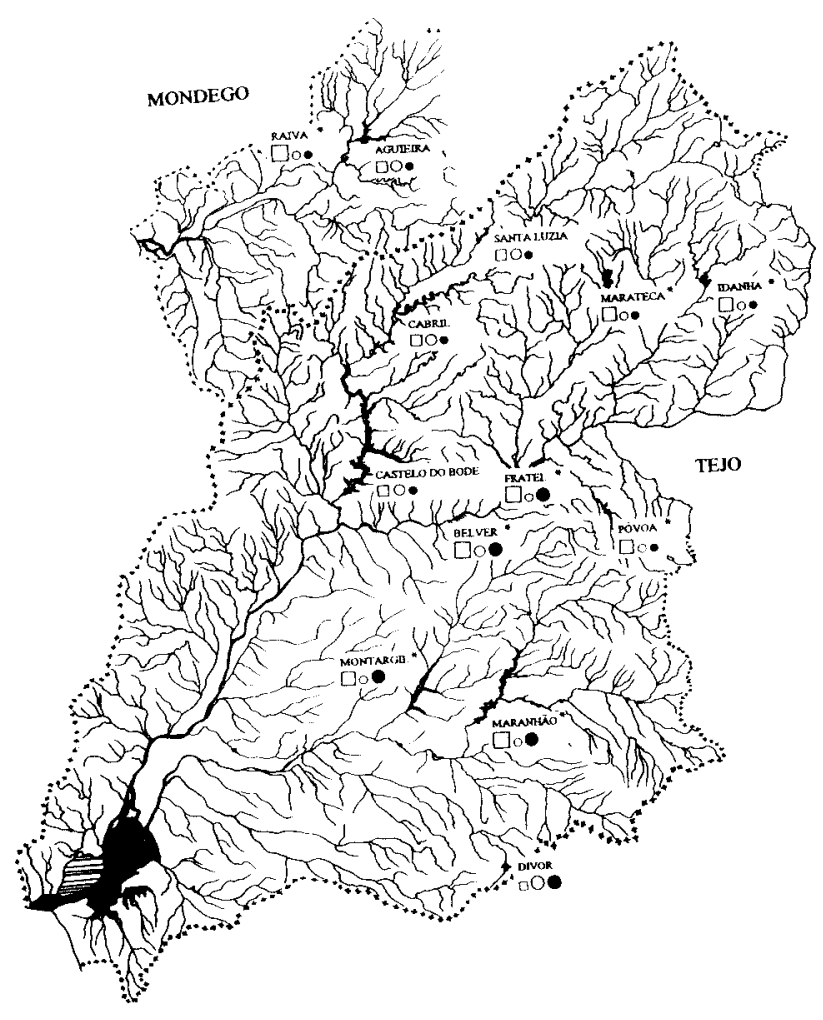

Figure 3. Location of reservoirs in rivers Mondego and Tejo watersheds. Relative magnitudes of TP $(\square)$, DO $(\mathrm{O})$, and water $\mathrm{pH}(\bullet)$ are provided, increasing quantities colresponding to increasings sizes of the respective symbols. Eutrophic reservoirs are marked with an asterisc.

Figura 3. Localización de los embalses en las cuencas de los ríos Mondego y Tajo. Se incluyen las magnitudes relativas de TP $(\square)$, DO $(\mathrm{O})$, y $\mathrm{pH}(\bullet)$ del agua. il través del tamaño creciente de los símbolos respectivos. Los embalses eutróficos se señalan con un asterisco.

Carlson's index the drainage basin of R. Sado contained the smallest percentage of eutrophic reservoirs, that of $R$. Tejo contained the largest percentage of eutrophic reservoirs: $15 \%$ and $64 \%$ respectively. $R$. Sado watershed is totally located in Portuguese territory, and in an area where rainfall is scarse, thus where recurrent drought years constitute the rule. Less rainfall implies less nutrients brought to the reservoirs by runoff. $\mathrm{R}$. Tejo drainage basin, on the other hand, is very large and extended over the territories of the two Iberian countries (Spain and Portugal) - there might be an accumulation effect in the Portuguese reservoirs, downhill with respect to a much larger area of the drainage basin, thereby also receiving materials from the neighbouring country area of the watershed.

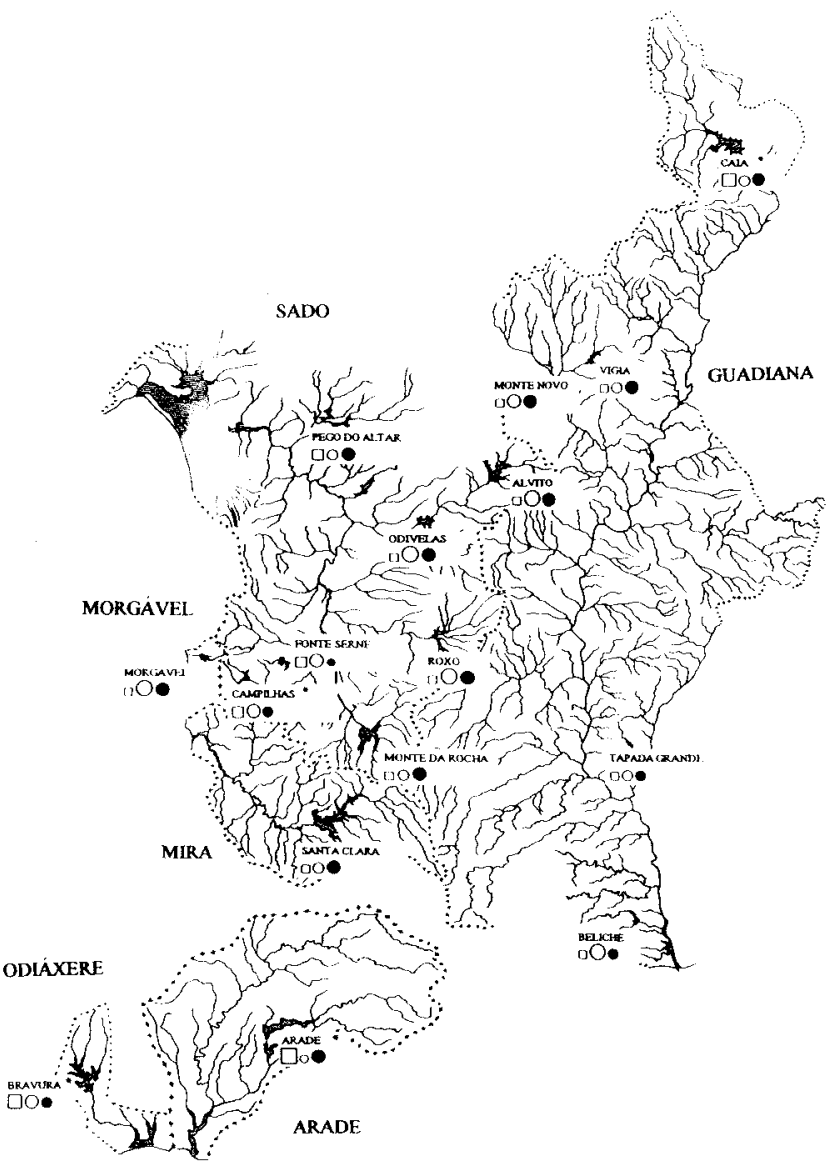

Figure 4. Location of reservoirs in rivers Guadiana, Sado. Morgável. Mira. Odiáxere, and Arade watersheds. Relative magnitudes of TP (O), DO (O), and water $\mathrm{pH}(\bullet)$ are provided, increasing quantities corresponding to increasing sizes of the respective symbols. Eutrophic reservoirs are marked with an asterise.

Figura 4. Localización de los embalses en las cuencas de los ríos Guadiana, Sado Morgável, Mira, Odiáxere y Arade. Se incluyen las magnitudes relativas de TP (), DO (O) y $\mathrm{pH}(\bullet)$ del agua, a través del tamaño creciente de los símbolos eutróficos se señalan con un asterisco.

\section{ACKNOWLEDGMENTS}

M.J. Caramujo kindly and skillfully draw the pictures. This research was partially supported by J.N.I.C.T. (Portugal) $842 / 90-$ RN doctoral grant to R.T.M. The paper is a contribution from Centro de Biologia Ambiental, Universidade de Lisboa. 


\section{REFERENCES}

ATLAS DO AMHIENTE. 1975. Distribution maps of insolation, temperature. precipitation - total amounts, precipitation -number of days in the year, air humidityrelative humidity at $9.00 \mathrm{~h} \mathrm{TMG}$, runoff - quantity of water in the hydrographic network, actual evapotranspiration (in Portuguese). Comissão Nacional do Ambiente.

ATLAS DO AMRIENTE. 1978. Distribution maps of soils (in Portuguese) Comissão Nacional do Ambiente.

ATLAS DO AMBIENTE. 1980. Distribution maps of population density (at county, regional level) (in Portuguese). Comissão Nacional do Ambiente .

CARLSON, R.E. 1977. A trophic state index for lakes. Limnol. Oceanogr. 22: 361-369.

MURPHY. J. \& J.P. RILEY. 1962. A modified simple solution method for the determination of phosphate in natural waters. Annal. Chem. Acta 27: 31 - 36.
VOLLENWEIDER. R.A. 1968. Water management research: Scientific fundamentals of the eutrophication of lakes and flowing waters with particular reference to nitrogen and phosphorus as factors in eutrophication. Paris: Organization for Economic Cooperation and Development, Committee for Research Cooperation.

VOLLENWEIDER, R.A. 1976. Advances in determining critical loading effects for phosphorus in lake eutrophication. Mem. Ist. Ital. Idrobiol. 33: 53-83.

WETZEL, R.G. 1983. Limnology. Saunders.

WETZEL, R.G. 1990. Reservoir ecosystems: Conclusions and speculations. Pp. 227-238 in Reservoir Limnology: Ecological Perspectives, K.W. Thornton, B.L. Kimmel, \& F.E. Payne, eds. John Wiley \& Sons.

WETZEL, R.G. 1996. Training of Aquatic Ecosystems Scientists. Pp. 218-233 in Freshwater Ecosystems: Revitalizing Educational Programs in Limnology. National Research Council, National Academy Press. 